\title{
ISOLASI BAKTERI DARI TANAH SEBAGAI PENGHASIL SENYAWA
}

\author{
Antimikrob Bacteria Isolation from Soils as Producing Antimicrob \\ Compounds
}

SUKMAWATI, FEBRIANTI ROSALINA

Universitas Muhammadiyah Sorong

Email: sukmawati.sw91@gmail.com

\begin{abstract}
Antibiotik adalah bahan obat yang sangat memegang peranan penting dalam menanggulangi penyakit infeksi. Senyawa antimikroba dapat diperoleh dari tumbuh-tumbuhan, dan mikroba. Senyawa antimikrob yang dihasilkan oleh mikroba memiliki keunggulan dibandingkan dengan antibiotik sintetik karena memiliki sifat yang lebih efektif, sebab targetnya spesifik serta toksisitasnya rendah. Tujuan dari penelitian yang telah dilakukan ialah untuk mengisolasi bakteri dari tanah yang mampu menghasilkan senyawa antimikrob, serta untuk menguji aktivitas penghambtannya terhadap pertumbuhan Escherichia coli dan Staphylococcus aureus. Metode yang telah digunakan dalam penelitian ini ialah isolasi, purifikasi, dan seleksi bakteri dari sampel tanah dengan metode uji penghambatan sedangkan bakteri Bacillus sp. Merupakan bakteri pembanding. Berdasarkan hasil penelitian yang diperoleh terdapat 2 isolat yang berpotensi memiliki aktivitas antimikroba yaitu isolat 1 dan isolate 4 . Isolat 1 lebih berpotensi menghambat $E$. coli dengan indeks hambat $4.0 \mathrm{~mm}$ dibandingkan dengan penghambatan $S$. aureus dengan indeks hambat $3.1 \mathrm{~mm}$. Sedangkan isolat 4 lebih berpotensi menghambat $S$. aureus dengan indeks hambat $2.8 \mathrm{~mm}$ dibandingkan dengan penghambatan terhadap $E$. coli dengan indeks hambat $1.4 \mathrm{~mm}$.
\end{abstract}

Kata Kunci: Antimikrob, E. coli, Isolasi, Bakteri Tanah, S. Aereus

\begin{abstract}
Abstrak
Antibiotics are medicinal ingredients that have an important role in tackling infectious diseases. Antimicrobial compounds can be obtained from plants, and microbes. Antimicrobial compounds produced by microbes have advantages over synthetic antibiotics because they have more effective properties, because the targets are specific and their toxicity is low. The purpose of the research was the isolate bacteria from the soil that is able to produce antimicrobial compounds, as well as to test its blocking activity against the growth of Escherichia coli and Staphylococcus aureus. The method that has been used in this study is the isolation, purification, and selection of bacteria from soil samples by inhibition test methods while the bacteria Bacillus sp. Is a comparative bacterium. Based on the research results obtained there are 2 isolates which have the potential to have antimicrobial activity, isolate 1 and isolate 4 . Isolate 1 has the potential to inhibit $E$. coli with inhibition index of $4.0 \mathrm{~mm}$ compared to $S$. aureus inhibition with $3.1 \mathrm{~mm}$ inhibition index. Whereas isolate 4 had more potential to inhibit $S$. aureus with a inhibition index of $2.8 \mathrm{~mm}$ compared to inhibition of $E$. coli with a inhibition index of $1.4 \mathrm{~mm}$.
\end{abstract}

Keywords: Antimicrobial, E. coli, Isolation, Soil Bacteria, S. aereus 
PENDAHULUAN Antibiotik adalah bahan obat yang sangat memegang peranan penting dalam menanggulangi penyakit infeksi. Senyawa antimikroba dapat diperoleh dari tumbuh-tumbuhan, dan mikroba. Senyawa antimikrob yang dihasilkan oleh mikroba memiliki keunggulan dibandingkan dengan antibiotik sintetik karena memiliki sifat yang lebih efektif, sebab targetnya spesifik serta toksisitasnya rendah (Utami, 2012).

Mikroorganisme penghasil antibiotika dapat diisolasi dari tanah, air laut, lumpur,kompos, isi rumen, limbah domestik, bahan makanan busuk dan lainlain. Tanah merupakan salah satu habitat bagi mikroorganisme, dalam satu gram tanah terdapat jutaan bakteri, fungi, protozoa dan mikroorganisme lainnya. Menurut Panagan (2011), populasi mikroorganisme dalam tanah di pengaruhi oleh beberapa faktor diantaranya jumlah dan jenis zat hara dalam tanah, kelembaban, tingkat aerasi, suhu, derajat keasaman, dan perlakuan yang diberikan pada tanah, seperti pemupukan.

Salah-satu bakteri yang dapat menghasilkan senyawa antimikrob adalah genus Bacillus. Bakteri golongan ini mampu menghasilkan senyawa antimikrob baik berupa antibiotik, proteinase maupun bakteriosin (Setiaji, 2019; Sukmawati \& Badaruddin, 2019).

Tujuan dari penelitian ini ialah untuk mengisolasi bakteri dari tanah yang mampu menghasilkan senyawa antimikrob, serta untuk menguji aktivitas penghambtannya terhadap pertumbuhan Escherichia coli dan Staphylococcus aureus.

\section{METODE}

Isolasi, Purifikasi, Seleksi Bakteri dari Sampel Tanah dan Bacillus sp. Terbaik dengan metode uji penghambatan

Pengambilan sampel tanah dilakukan di area Dramaga dengan cara mengambil sampel tanah dari kedalaman sekitar $5 \mathrm{~cm}$. Sebanyak $1 \mathrm{~g}$ sampel tanah dilarutkan dalam akuades $9 \mathrm{~mL}$ sebagai pengenceran $10^{-1}$. Pengenceran sampel dilakukan secara serial dari konsentrasi $10^{-1}$ hingga $10^{-5}$. Kemudian untuk pengenceran $10^{-4}$ di plate spread pada dua cawan petri, untuk perlakuan 1 ditambahkan bakteri uji $0.2 \mathrm{~mL}$ E. coli, perlakuan 2 ditambahkan $S$. Aereus $0.2 \mathrm{~mL}$ dan perlakuan 3 dengan seri pengenceran $10^{-5}$ tanpa bakteri uji. Selain isolasi bakteri dari tanah, juga meremajakan isolat Bacillus sp. dengan pengenceran $10^{-1}-10^{-5}$. Perlakuan pertama yaitu pengenceran $10^{-1}$ diperlakukan dengan cara heat shock pada suhu $80^{\circ} \mathrm{C}$ $90^{\circ} \mathrm{C}$ selama1-3menit, kemudian di inoukulasikan pada media Nutrien Agar (NA) dengan cara spread plate (metode sebar) masing-masing ditambah $1 \mathrm{~mL}$ suspense $0.2 \mathrm{~mL}$ E. coli untuk perlakuan 1 , perlakuan 2 ditambahkan $S$. aereus $0.2 \mathrm{~mL}$ dan perlakuan 3 tanpa bakteri uji. Masingmasing perlakuan yang telah diinokulasikan pada media NA diinkubasi pada suhu ruang selama 3 hari.

Purifikasi isolate bakteri dari sampel tanah dan Bacillus sp. Dilakukan dengan cara memilih isolat bakteri yang menghasilkan zona hambat (zona bening disekitar koloni). Kemudian koloni bakteri yang menghasilkan zona hambat diinokulasikan dengan metode gores kuadran pada media NA, kemudian diinkubasi selama 2-3 hari yang selanjutnya dipurifikasi pada agar miring. Selanjutnya isolate bakteri dengan cara memilih isolate bakteri yang tumbuh, kemudian diinokulasikan pada media NA dengancara gores titik dan diinkubasi selama 2-3 hari pada suhu ruang. Bakteri Bacillus sp. Digunakan sebagai pembanding dengan isolate bakteri yang telah diisolasi dari sampel tanah.

Indeks aktivitas penghambatan dihitung berdasarkan rumus:

Zona hambat $(\mathrm{mm})=\frac{\text { zona bening-zona koloni }}{\text { zona koloni }}$

(Sukmawati, 2018)

Uji aktifitas penghambatan Bakteri dari Sampel Tanah dan Bacillus sp. Pada kultur E.coli dan S.aureus

Dua isolat terbaik diambil pada stock kemudian ditumbuhkan pada media 
Nutrien Broth (NB) . Inkubasi dilakukan selama 3-4 hari pada suhu ruang, setelah itu disentrifugasi selama 15 menit pada suhu $4^{0} \mathrm{C}$ dengan kecepatan $6000 \mathrm{rpm}$. Supernatan yang dihasilkan diambil dan diteteskan pada kertas cakram. Kertas cakram yang mengandung supernatant Bacillus sp. Diletakkan dalam media NA yang berbeda yaitu media NA yang mengandung kultur E.coli dan media NA yang mengandung kultur S.aureus. Selanjutnya diinkubasi dilakukan pada suhu ruang selama 2-3 hari, kemudian diukur zona hambatnya dan diukur indeks aktifitas penghambatannya.

\section{HASIL DAN PEMBAHASAN}

Hasil isolasi bakteri dari sampel tanah dan Bacillus sp. Diperoleh 2 isolat bakteri dari sampel tanah yang dapat menghasilkan zona hambat (zona bening) dengan kemampuan dapat menghambat $E$. coli dan S. areus . Sedangkan Isolat Bacillus sp. Hanya mampu menghambat S.Areus (Gambar 1 dan Tabel 1).

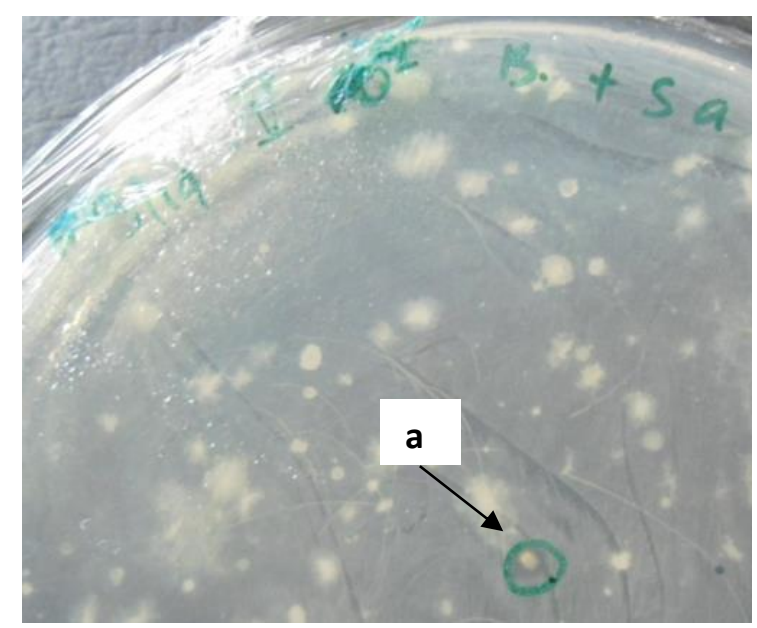

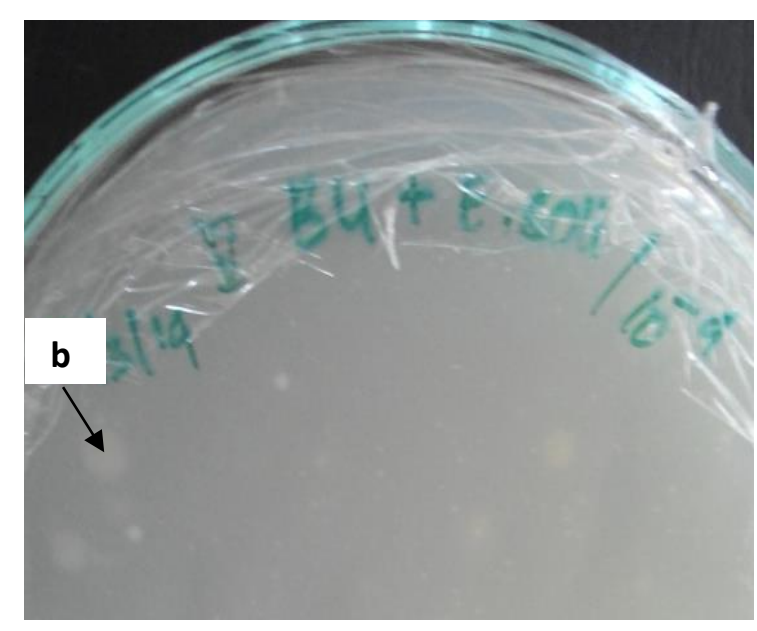

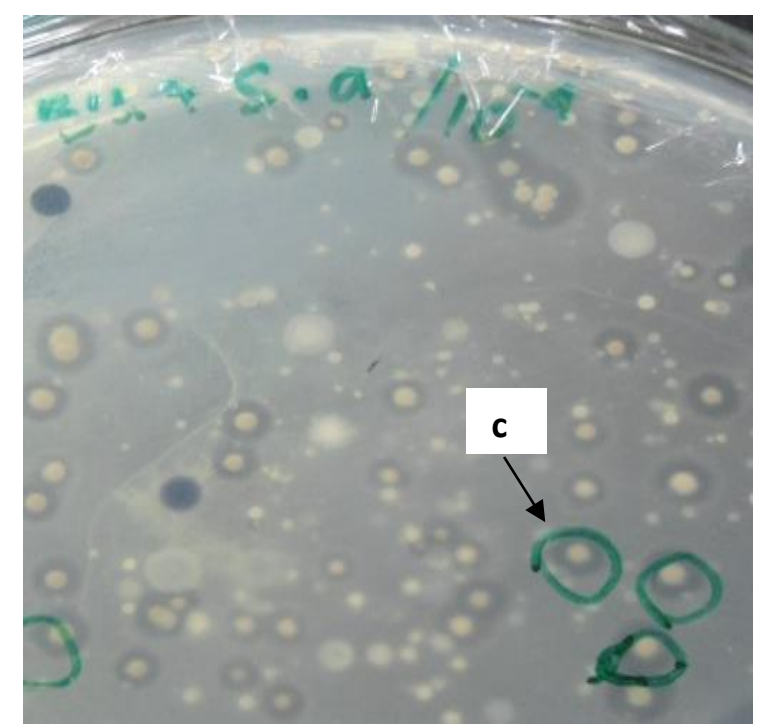

Gambar 1. Hasil isolasi dan aktifitas penghambatan Bakteri dari Isolat Sampel Tanah (IST) dan Bacillus sp. (a; Bacillus sp. Vs S.areus, b; Isolat 1 vs E.coli, c; Isolat 4 vs S.areus)

Uji aktifitas penghambatan isolat 1 dan 4 yang berasal dari sampel tanah terhadap E.coli dan $S$. aureus dengan menggunakan kertas cakram lebih rendah nilai hambatnya disbanding dengan tidak menggunakan kertas cakram (Gambar 2 dan Tabel 1) 

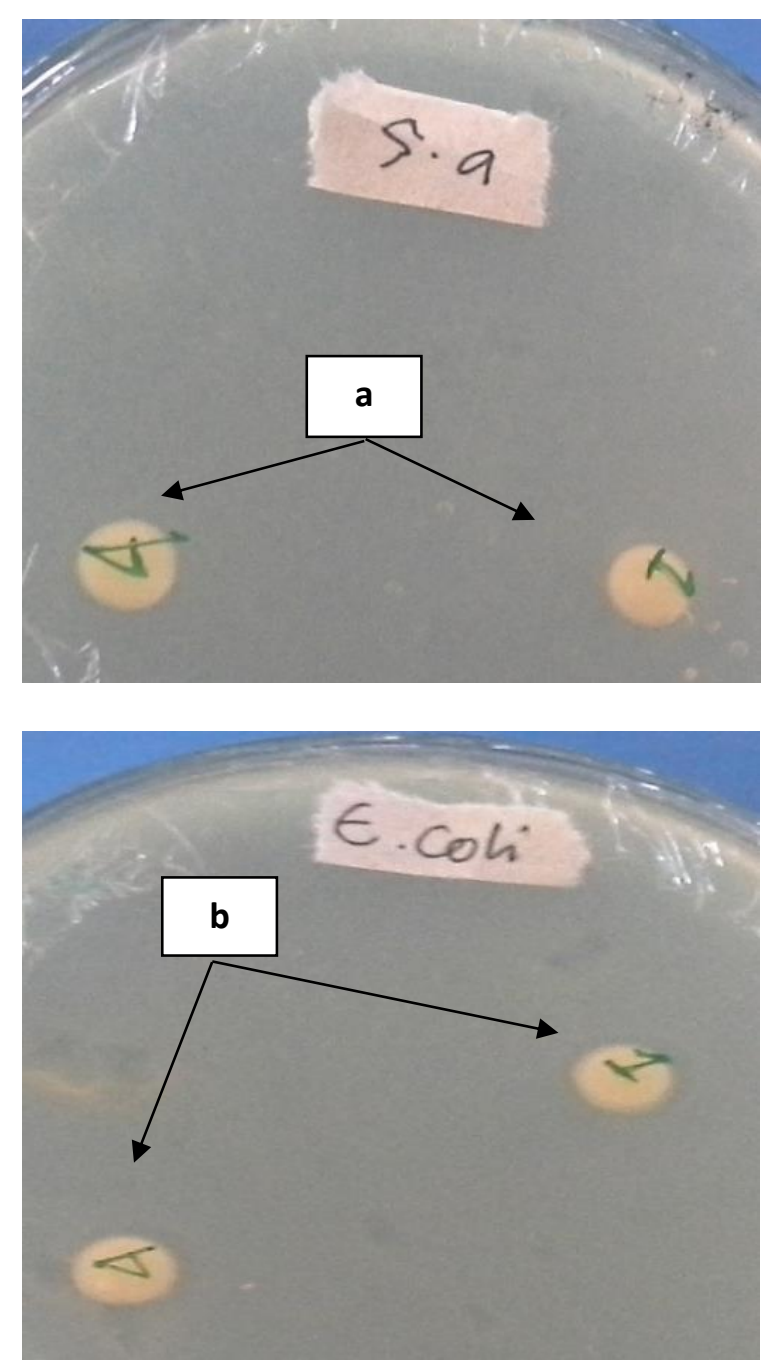

Gambar 2. Aktivitas zona hambat isolat 1 dan isolate 4 dalam menghambat $S$. aureus dan E.coli (a; isolat $1 \& 4$ vs $S$. aureus, b; isolat $1 \& 4$ vs E.coli).

Tabel 1. Indeks zona hambat isolate bakteri asal tanah tanpa menggunakan kertas cakram dan mengunakan kertas cakram

\begin{tabular}{|c|c|c|c|c|}
\hline \multirow{3}{*}{ Isolat } & \multicolumn{4}{|c|}{ Indeks Zona Hambat (mm) } \\
\hline & \multicolumn{2}{|c|}{$\begin{array}{l}\text { Isolat } \\
\text { Sampel } \\
\text { tanah Vs } \\
\text { E.coli }\end{array}$} & \multicolumn{2}{|c|}{$\begin{array}{c}\text { Isolat } \\
\text { Sampel } \\
\text { tanah Vs } S . \\
\text { aereus }\end{array}$} \\
\hline & $\begin{array}{c}\text { Tanpa } \\
\text { cakra } \\
\text { m }\end{array}$ & $\begin{array}{c}\text { Mengguna } \\
\text { kan } \\
\text { cakram }\end{array}$ & $\begin{array}{c}\text { Tanp } \\
\mathrm{a} \\
\text { cakra } \\
\mathrm{m}\end{array}$ & $\begin{array}{c}\text { Menggu } \\
\text { nakan } \\
\text { cakram }\end{array}$ \\
\hline 1 & 4.0 & 2.1 & 3.1 & 3.1 \\
\hline 4 & 1.4 & 1.2 & 2.8 & 2.6 \\
\hline
\end{tabular}

Berdasarkan hasil penelitian, terdapat 2 isolat yang berpotensi memiliki aktivitas antimikroba yaitui isolat 1 dan isolat 4 , Isolat 1 lebih berpotensi menghambat $E$. coli dengan indeks hambat $4.0 \mathrm{~mm}$ dibandingkan dengan aktivitas nilai hambatnya pada $S$. aureus dengan indeks hambat $3.1 \mathrm{~mm}$. Sedangkan isolat 4 lebih berpotensi menghambat $S$. aureus dengan indeks hambat $2.8 \mathrm{~mm}$ dibandingkan dengan penghambatan $E$. coli dengan indeks hambat $1.4 \mathrm{~mm}$. E. coli merupakan bakteri gram negative sedangkan $S$. aureus merupakan bakteri gram positif. Bakteri $E$. coli dan $S$. aureus merupakan bakteri pathogen dan pada umumnya merupakan bakteri terbawa makanan (Anggraini, 2019; Hardianti, 2019; Sukmawati \& Hardianti, 2018; Sukmawati, et al. 2018). Kedua bakteri tersebut dapat mewakili masingmasing kelompok bakteri berdasarkan perbedaan struktur dinding sel yang dikandungnya.

Secara umum, mekanisme antibiotik dalam menghambat pertumbuhan bakteri gram positif dan gram negative memiliki perbedaan. Mekanisme antibiotic spesifik dalam menghambat bakteri gram positif dengan cara menghambat sintesis peptidoglikan. Menurut Martha (2015) antibiotik beta laktam bekerja dengans pesifik menghambat sintesis peptidoglikan bakteri. Beta lactam dapat menghambat transpeptidase dan D-alanin karboksipeptidase yang dapat mengkatalis polimerisasi rantai peptidoglikan (Suarez, 2009).

Antibiotik ini dapat membunuh sel yang sedang tumbuh tetapi tidak membunuh sel yang berada dalam fase stasinoener (Wahjono, et al., 2015). Salah satu contoh antibiotic beta laktam yang tersebar luas adalah penisilin. Antibiotik jenis beta lactam yang tersebar luas dapat mengatasi banyak penyakit infeksi bakteri, namun dampak terburuk yang terjadi ialah dengan timbulnya galur yang resisten terhadap antibiotik beta laktam. Galur yang resisten tersebut memiliki enzim beta laktamase yang dapat berikatan dengan senyawa beta lactam (Kambuno, 2017). 
Sedangkan mekanisme antibiotik dalam menghambat bakteri gram negatif relative berbeda dibandingkan dengan gram positif. Bakteri gram negative memiliki sedikit peptidoglikan sehingga membutuhkan jalur lain dalam proses penghambatannya. Salah satu contoh antibiotik yang dapat menghambat bakteri gram negative dan cukup tersebarluas adalah streptomisin. Streptomisin merupakan antibiotic aminoglikosida yang spesifik menghambat sintesis protein dengan cara mengikat protein ribosomal S12 pada subunit 30S (Okamoto, 2007).

Protein ribosomal S12 aktif pada konstituen A-site dalam pengikatan aminoasil-tRNA dan met-tRNA. Antibiotik streptomisism juga mengandung 2deoxystreptamine yang dapat menghambat translokasipeptidil-tRNA. Sedangkan aminoglikosida juga merusak membrane sel bakteri gram negative, sehingga menyebabkan hilangnya permeabilitas membrane terhadap komponen sel. Karena, alasan mekanisme penghambatannya tersebut, olehnya itu aplikasi streptomisin dapat berefek pada manusia sebab, manusia memiliki target sasaran dari streptomisin itu sendiri, yang mana manusia memiliki subunit 30S pada ribosom mitokondria (Singh, et al., 2015).

Pada penentuan jenis antibiotik yang terkandung dalam isolat 1 dan 4 dibutuhkan penelitian lebih lanjut seperti pemurnian senyawa menggunakan kromatografi, analisa dalam penelitian yang telah dilkukan merupakan gambaran mekanisme secara umum pada antibiotic yang dapat menghambat bakteri gram positif dan gram negative seiring dengan isolate 1 yang berpotensi menghambat bakteri gram negative yang di wakili oleh $E$. coli dan isolate 4 yang berpotensi menghambat bakteri gram positif yang diwakili oleh $S$. aureus.

\section{KESIMPULAN}

Berdasarkan hasil penelitian yang diperoleh terdapat 2 isolat yang berpotensi memiliki aktivitas antimikroba yaitu isolat 1 dan isolate 4. Isolat 1 lebih berpotensi menghambat $E$. coli dengan indeks hambat $4.0 \mathrm{~mm}$ dibandingkan dengan penghambatan $S$. aureus dengan indeks hambat $3.1 \mathrm{~mm}$. Sedangkan isolat 4 lebih berpotensi menghambat $S$. aureus dengan indeks hambat $2.8 \mathrm{~mm}$ dibandingkan dengan penghambatan terhadap $E$. coli dengan indeks hambat $1.4 \mathrm{~mm}$.

\section{DAFTAR PUSTAKA}

Angraini, E., Angraeni, D. N., Umami, S. S., Sumiati, E., \& Taufiqurokhman, T. (2019, February). Antagonism of Lentinus Cladopus Lc4 Extract, Trichoderma sp. Jpa Extract on Bacillus sp., Xanthomonas sp. and E. Coli. In Journal of Physics: Conference Series (Vol. 1155, No. 1, p. 012057). IOP Publishing.

Dewi, A. (2007). Uji Sensitivitas Staphylococcus Aureus Dari Pus Pasien Di Rumah Sakit Umum Pusat Dr. Soeradji Tirtonegoro Klaten Terhadap Beberapa Antibiotik (Doctoral dissertation, Univerversitas Muhammadiyah Surakarta).

Hardianti, F., \& Aziz, I. R. (2019). Identification of Pathogenic Bacteria on the Salted Fish Lutjanus Vivanus in Sorong City of West Papua.Malaysian Journal of Microbiology, 15(3), 237-244.

Kambuno, N. T., \& Fanggidae, D. (2017). Identifikasi Bakteri Gram Negatif Galur Extended Spectrum Beta Lactamase Pada Ruang NICU RSUD Prof. DR. WZ Johannes Kupang. Jurnal Info Kesehatan, 15(2), 333-345.

Martha, D. (2015). Perbandingan Hasil Uji Kepekaan Escherichia Coli Terhadap Seftriakson Dengan Siprofloksasin Di Rumah Sakit Al-Islam Pada Tahun 2014.

Okamoto, S., Tamaru, A., Nakajima, C., Nishimura, K., Tanaka, Y., Tokuyama, S., ... \& Ochi, K. (2007). Loss of a conserved 7- 
methylguanosine modification in $16 \mathrm{~S}$

rRNA confers low-level streptomycin resistance in bacteria. Molecular

microbiology, 63(4), 1096-1106.

Panagan, A. T. (2011). Isolasi Mikroba Penghasil Antibiotika dari Tanah Kampus Unsri Indralaya Menggunakan Media Ekstrak Tanah. Jurnal Penelitian Sains, 14(3).

Setiaji, J. (2019). Analisis Dna Bakteri Heterotrofik Laut Yang Bersifat Antagonis Terhadap Bakteri Patogen Pada Ikan. Prosiding Seminakel, 1(1).

Singh, A. K., Drolia, R., Bai, X., \& Bhunia, A. K. (2015). Streptomycin induced stress response in Salmonella enterica serovar Typhimurium shows distinct colony scatter signature. PloS one, 10(8), e0135035.

Suarez, C., \& Gudiol, F. (2009). Betalactam antibiotics. Enfermedades infecciosas y microbiologia clinica, 27(2), 116-129.

Sukmawati, S. (2018). Isolasi Bakteri Selulolitik dari Limbah Kulit Pisang. Biotropic: The Journal of Tropical Biology, 2(1), 46-52.

Sukmawati, S., \& Badaruddin, M. I. (2019). Screening of Probiotic Bacteria Candidates in The Mangrove Tourism Area in Klawalu Sorong City West Papua. Bioscience, 3(2), 161-168.

Sukmawati, S., \& Hardianti, F. (2018). Analisis Total Plate Count (TPC) Mikroba pada Ikan Asin Kakap di Kota Sorong Papua Barat. Jurnal Biodjati, 3(1), 72-78.

Sukmawati, S., Ratna, R., \& Fahrizal, A. (2018). Analisis Cemaran Mikroba Pada Daging Ayam Broiler Di Kota Makassar. Scripta Biologica, 5(1), 51-53.

Utami, E. R. (2012). Antibiotika, resistensi, dan rasionalitas terapi. Sainstis.

Wahjono, H., Radjasa, O. K., Sabdono, A., Khoeri, M. M., \& Karyana, E. (2015).
Antimycobacterial Activities from Seagrass Enhalus sp. Associated Bacteria Against Multi Drug Resistance Tuberculosis (MDR TB) Bacteria. Procedia Environmental Sciences, 23, 253-259. 